\title{
Chemical Scarification, Moist Prechilling, and Thiourea Effects on Germination of 18 Shrub Species
}

\author{
N.D. STIDHAM, R.M. AHRING, J. POWELL AND P.L. CLAYPOOL
}

\begin{abstract}
Establishment is a major problem of increasing palatable shrubs on rangeland; therefore the objective of this study was to determine the effects of chemical scarification, moist prechilling, and thiourea on seed germination in 18 different shrub species. Scarification for various periods in concentrated sulfuric acid, 10\% hydrogen peroxide, and $5.25 \%$ sodium hypochlorite (clorox) produced unchanged or reduced germination, except for one hydrogen peroxide treatment of bitterbrush. Moist prechilling prior to germination was conducted on vermiculite moistened with distilled water or $0.2 \%$ potassium nitrate for periods up to 16 weeks. In general, prechilling yielded maximum germination, without respect to moistening agent. Seeds treated with thiourea were soaked for periods up to $1 \mathrm{hr}$ in a $0.3 \%$ solution. Thiourea treatments were ineffective in increasing germination. On the basis of their germination response to prechilling treatments, bitterbrush, shadscale, big sagebrush, cliffrose, curlleaf mountain mahogany, and golden currant are recommended for fall planting. Apache plume, shrubby cinquefoil and Morman tea could be planted in spring or fall, and winterfat, fourwing saltbush, and Jersey tea should be planted in spring. Constraints other than seed germination, not studied here, must also be considered in planting shrubs for range improvement.
\end{abstract}

The importance of seasonal availability of palatable range shrubs and their adaptation and establishment on selected range sites has received little attention in other than the western range states. This area of range improvement is recognized in the western states (Cable 1972; Stevens et al. 1977) but direct seeding of desirable native shrubs has met with limited success. Poor stands are often attributed to poor seed germination. Seeds which do not germinate under favorable conditions, but may be induced to germinate, are considered dormant (Mayer and Poljakoff-Mayber 1975). Immature embryos, impermeability of seed coat to water or gases, mechanical causes, light and temperature requirements, or the presence of germination inhibitors are factors which may cause seed dormancy.

Chemical and mechanical scarification, stratification, subjecting seeds to temperature extremes, soaking seeds in various concentrations of thiourea solutions, gibberellic acid, and combinations of one or more treatments have been used to break seed dormancy (Carlson 1974; Everett and Meeuwing 1975; Liacos and Nord 1961; McConnell 1960; McHenry and

\footnotetext{
Authors are graduate research assistant; research agronomist, SEA-USDA: associate professor of range science; and associate professor of statistics, Oklahoma State Univ. Stillwater 74074 .

This research is a contribution of the Oklahoma Agricultural Experiment Station as Journal Article No. 3587.

At present Stidham is environmental specialist, Shell Oil Company, Houston, Texas. Manuscript received January 5, 1979.
}

Jensen 1967; Pearson 1957; Walters 1970).

A hard seed-coat may be impermeable to water, gases, or may constrain the embryo. Scarification (seed coat abrasion/ erosion) treatments are used to erode the seed-coat to improve permeability (Amen 1963). Stratification (moist chilling) is believed to limit the effects of inhibitors while promoting growth stimulators such as gibberellic acid. Dilute solutions of potassium nitrate and gibberellic acid are growth stimulators and different concentrations have been used to promote germination of certain species (Mayer and Paljakoff-Mayber 1975; Young et al. 1978). Mirov (1936) observed that stratification treatments increased germination of seeds from plants growing at elevations greater than $1,200 \mathrm{~m}$, while scarification treatments, in some instances, increased germination for species growing at elevations less than $300 \mathrm{~m}$. Considerable difficulty has been encountered by others in establishing palatable shrub species by direct seeding. With this in mind, the objective of our study was to determine the effects of different pre-germination treatments on germination of 18 shrub species, from diverse origins.

\section{Methods}

Since seed and availability of palatable shrubs in Oklahoma are limited and the importance of shrubs as livestock browse generally is not recognized, most of the species studied are mountainous or intermountainous in origin. Only Atriplex spp., Apache plume (Fallugia paradoxa), and mountain-mahogany (Cercocarpus spp.) have been evaluated for use in the Southern Plains (Shopmeyer 1974).

Species selected for evalution and study were bitterbrush (Purshia tridentata), fourwing saltbush (Atriplex canescens), inland Jersey tea (Ceanothus ovatus), serviceberry (Amelanchier alnifolia), big sagebrush (Artemisia tridentata), shadscale (Atriplex confertifolia), snowbrush (Ceanothus velutinus), winterfat (Ceratoides lanata), curl leaf mountain-mahogany (Cercocarpus ledifolius), cliffrose (Cowania mexicana var. stansburiana), Morman tea (Ephedra viridus), Apache-plume, prostrate kochia (Kochia prostrata), shrubby cinquefoil (Potentilla fruticosa), golden currant (Ribes aureum), woods rose (Rosa woodsii). wedgeleaf ceanothus (Ceanothus cuneatus), and chamise (Adenostoma fasciculatum). Scientific nomenclature is according to Soil Conservation Service (1971) and USDA Forest Service (1977).

Criteria for selecting those species with potential for Oklahoma rangeland conditions were the availability of seed and reported utilization and winter nutritive value for livestock and big-game. Seeds were obtained from Soil Conservation Service Plant Materials Centers and from commercial seed sources. After processing each seed lot to remove inert appendages (e.g., the winged appendages of fourwing saltbush), heavy, well-filled seeds were separated from the 
light, empty, or immature seeds with a South Dakota seed blower ${ }^{1}$. All seeds utilized in germination studies were counted by hand and considered uniformly well-filled complete seed units. Processing, if any, and storage conditions of seed prior to initiation of study were not known.

Pre-germination treatments (chemical scarification, moist prechilling, and soaking in thiourea $\left(\left(\mathrm{NH}_{2}\right)_{2} \mathrm{CS}\right)$ were replicated 3 times with 25 seeds in each replication. Germination studies were arranged in a randomized complete block design and conducted in a Stultz germinator set for alternating temperatures of $12.5^{\circ}$ (night and $20^{\circ} \mathrm{C}$ (day) for 16 and $8 \mathrm{hr}$, respectively. Containers used for all germination studies were clear plastic germination boxes $7 \times 7 \times 3 \mathrm{~cm}$ containing $70 \mathrm{ml}$ of vermuculite below the seed zone and $30 \mathrm{ml}$ above. A uniform volume of water was added to the vermiculite in each box. Each scarification, moist prechill, and thiourea-soaking treatment involving different treatment durations was terminated simultaneously (i.e., 16-week prechill treatment ended at the same time as the 2-week treatment). Germination counts were made at 7-day intervals for a period of 4 weeks. Seeds were considered germinated when cotyledon or hypocotyl emergence was evident.

Only seeds of bitterbrush, fourwing saltbush, and Jersey tea were used in the scarification experiments, because of a limited supply of seed of other species. Chemical scarification treatments were concentrated sulfuric acid $\left(\mathrm{H}_{2} \mathrm{SO}_{4}\right), 10 \%$ hydrogen peroxide $\left(\mathrm{H}_{2} \mathrm{O}_{2}\right)$, and $5.25 \%$ sodium hypochlorite $(\mathrm{NaOC} 1)$. The seeds were soaked in each chemical for $0,3,6,9$, or 12 hrs. The control consisted of no pretreatment of the seed prior to germination. Seeds removed from each chemical scarification solution were thoroughly washed under running tap-water, and placed in germination boxes in the germinator.

Pregermination chilling treatments consisted of placing the seeds in germination boxes filled with vermiculite, moistening with the appropriate solution of either $0.2 \%$ potassium nitrate $\left(\mathrm{KNO}_{3}\right)$ or distilled water, and chilling in the dark at $2^{\circ} \mathrm{C}$. Bitterbrush, fourwing saltbush, and Jersey tea seeds were subjected to chill durations of 0 , 2,8 , and 16 weeks. Because of insufficient seed, the remaining species were prechilled prior to germination for 0,2 , and 10 weeks. The lid of each box was sealed with tape to prevent evaporation loss during prechill.

Thiourea treatments consisted of soaking seeds in a $0.3 \%$ solution of thiourea for $0,20,40$, and $60 \mathrm{~min}$. The control consisted of no pre-soaking of the seed. Following treatment, seeds were washed under running tap-water, transferred to germination boxes, and placed in the germinator.

All data were analyzed on an IBM $370 / 158$ computer using the ANOVA procedure of the Statistical Analysis System (Barr and Goodnight 1972). All differences discussed were statistically significant at the $5 \%$ level of probability unless otherwise stated.

\section{Results and Discussion}

\section{Scarification}

The effects of chemical scarification treatments on seed germination depended upon the chemical and soaking duration. Scarification with hydrogen peroxide produced the highest average seed germination while scarification with sulfuric acid produced the lowest (Fig. 1). With the exception of bitterbrush seeds scarified for $6 \mathrm{hr}$ in hydrogen peroxide, scarification reduced germination below that of the control in all species. Treated bitterbrush and Jersey tea seeds failed to germinate after soaking in concentrated sulfuric acid.

Clorox and concentrated sulfuric acid appear to be too harsh for seed scarification of all three of these shrub species. Soaking the seeds in less concentrated solutions or for shorter durations with all three chemicals studied may have altered the

\footnotetext{
${ }^{1}$ Mention of a trade mark of proprietory product does not constitute a guarantec or warranty of the product by Oklahoma State University and does not imply approval to the exclusion of other products that may also be suitable.
}
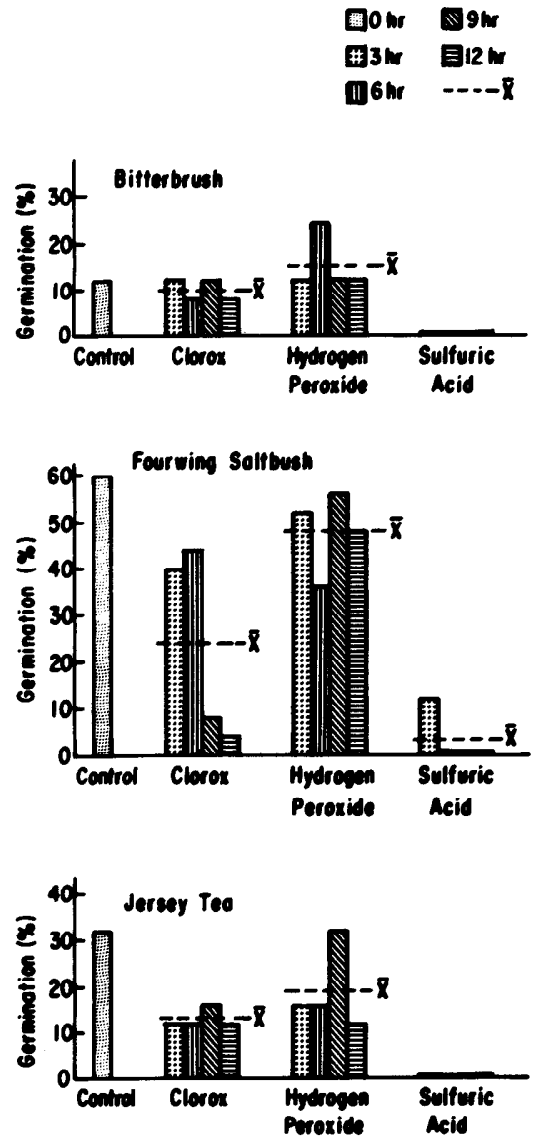

Fig. 1. Germination of three browse species in response to three chemicals and four soaking time intervals. Time $\times$ Treatment $L S D_{0.05}:$ bitterbrush, 5.8; fourwing saltbush, 8.0; Jersey tea, 5.5.

results of this study.

Moist Prechill, Distilled Water and $\mathrm{KNO}_{3}$

Compared to distilled water as a substrate-moistening agent during prechill, a $0.2 \% \mathrm{KNO}_{3}$ solution did not increase germination of bitterbrush, Jersey tea, or fourwing saltbush seed. Regardless of moistening agent, prechill increased seed germination of all three species (Fig. 2). A direct relationship existed between the mean germination of bitterbrush seeds and length of prechill duration with both moistening agents. Maximum germination of bitterbrush seeds occurred following the 16-week prechill treatment, whereas germination of fourwing saltbush and Jersey tea seeds decreased when subjected to moist prechill durations beyond 2 weeks. Fourwing saltbush and bitterbrush seeds began to germinate while in the prechill environment $\left(2^{\circ} \mathrm{C}\right)$ in the 8- and 16-week treatment duration.

Germination averages of Morman tea and shrubby cinquefoil seeds (Fig. 3) were greater when prechilled on substrate moistened with distilled water. Maximum germination of winterfat occurred when seeds received no prechill treatment and were germinated on vermiculite moistened with distilled water. There was an indirect relationship between winterfat seed germination and length of prechill treatments using distilled water as substrate moistening agent.

Big sagebrush, curlleaf mountain-mahogany, cliffrose, and golden currant had greater germination averages when prechilled on substrate moistened with $\mathrm{KNO}_{3}$ (Fig. 4). Germination of shadscale seeds when prechilled on substrate 

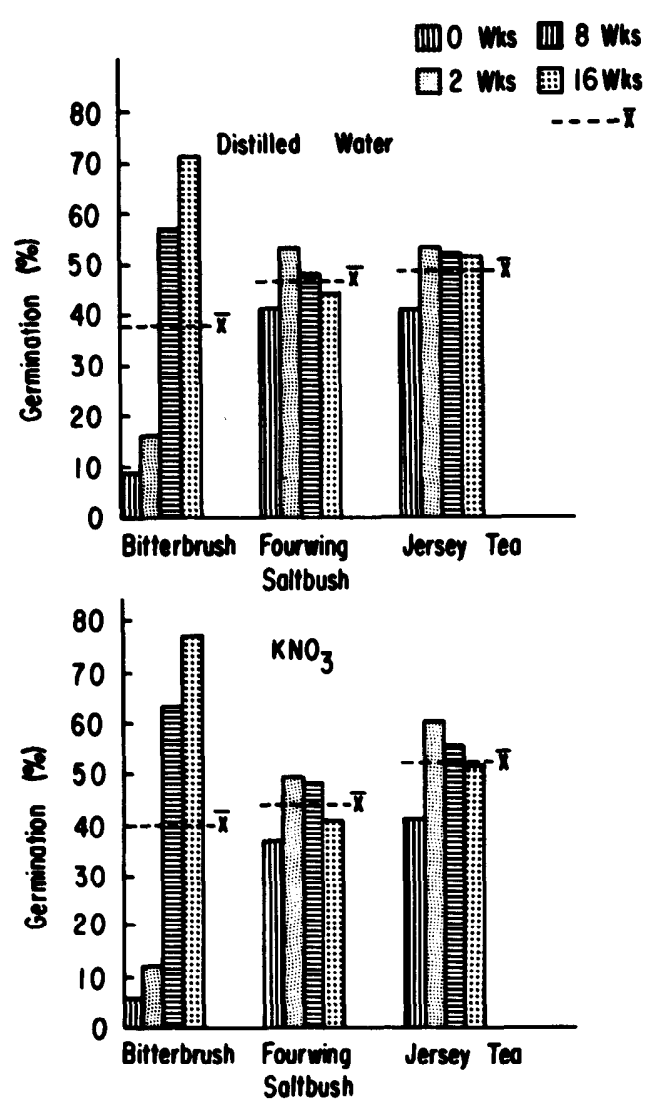

Fig. 2. Germination of three browse species in response to two moistening agents on seeds prechilled for $0,2,8$, and 16 weeks. Time $\times$ Treatment $L S D_{0.05}$ : bitterbrush, 4.2; fourwing saltbush, 5.7; Jersey tea, 4.4.

moistened with $0.2 \% \mathrm{KNO}_{3}$ was sufficiently high to suggest that longer prechill durations may induce a greater number of seeds to germinate. Neither moistening agent nor prechill duration had much effect on germination of Apache-plume.

In general, the use of $0.2 \% \mathrm{KNO}_{3}$ solution as substrate moisture without prechill had no beneficial effect on seed germination over distilled water. However, in combination with prechill the use of $\mathrm{KNO}_{3}$ on seed germination had (1) a beneficial effect on seeds of big sagebrush, shadscale, curlleaf mountain-mahogany, cliffrose, and golden currant; (2) little or no effect on others such as Apache-plume; and (3) a threshold

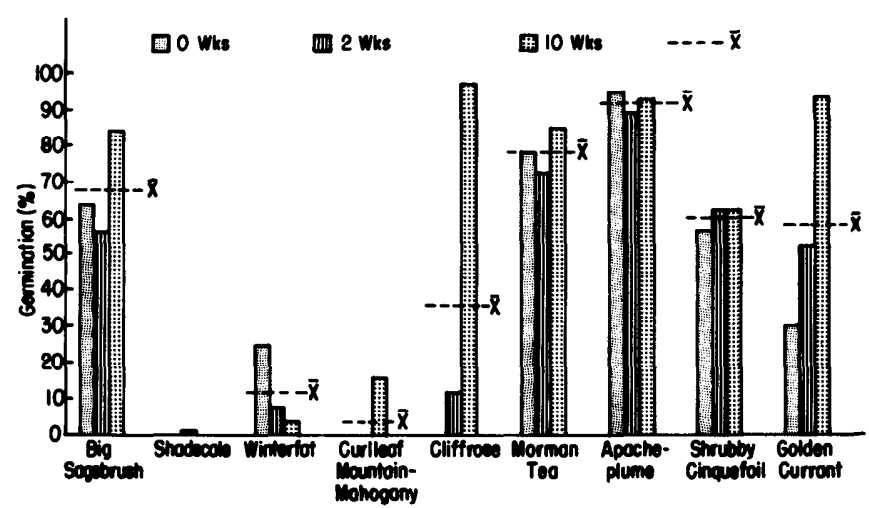

Fig. 3. Germination effects of distilled water as a moistening agent on seeds of nine browse species prechilled for 0,2 , and 10 weeks. Time $\times$ Treatment LSD ${ }_{0.05}$ : big sagebrush, 30.0; shadscale, 12.0; winterfat, 7.6; curlleaf mountain-mahogany, 9.5; cliffrose, 7.3; Morman tea, 14.6; Apacheplume, 17.4; shrubby cinquefoil, 17.3; golden currant, 18.2 antagonism to winterfat and shrubby cinquefoil. Regardless of prechill duration, the $0.2 \% \mathrm{KNO}_{3}$ substrate moistening agen had a tendency to delay seed germination during the first $7 \mathrm{tc}$ 14 days of incubation. However, this delayed effec disappeared as prechill duration increased.

Potassium nitrate appeared to stimulate early germination of goldent currant. With the exceptions of winterfat, Apache plume and shrubby cinquefoil, seed germination of all species studied responded to moist prechill. Apache-plume seeds germinated readily regardless of treatment combination

A direct relationship was observed, for most species, tc exist between maximum germination and prechill treatmen duration. Maximum germination of big sagebrush, shadscale curlleaf mountain-mahogany, cliffrose, Morman tea, anc golden currant was attained after a 10 -week prechill duration The need for moist prechill durations longer than 10 weeks tc attain maximum seed germination of shadscale and curlleaf mountain-mahogany was evident.

Regardless of substrate-moistening agent used during prechill or duration of prechill, serviceberry, snowbrush, prostrate kochia, woods rose, chamise, and wedgeleal caenothus failed to germinate or germinated less than $5 \%$. Ou data suggest that germination of snowbrush and wedgeleal ceanothus seeds might have been greater if prechill durations with either moistening agent had been longer. Apparently treatments other than moist prechilling are required tc germinate seeds of serviceberry prostrate kochia, and woods rose.

\section{Thiourea}

Golden currant was the only species for which thiourea promoted germination. Maximum germination of golden currant seeds occurred after seeds were soaked for $\mathbf{4 0 ~} \mathrm{min}$ in a $0.3 \%\left(\mathrm{NH}_{2}\right)_{2} \mathrm{CS}$ solution prior to germination.

Bitterbrush, Jersey tea, winterfat, prostrate kochia, and shrubby cinquefoil seed germination results were similar to those obtained by Pearson (1957). He observed an inverse relationship between the concentration of thiourea and length of soaking time required for increased bitterbrush seed germination.

Interactions between light, temperature, and thiourea concentration affect seed germination (Mayer and PoljakoffMayber 1975). Apparently the concentration of the thiourea solution used in this study was too low and soaking time
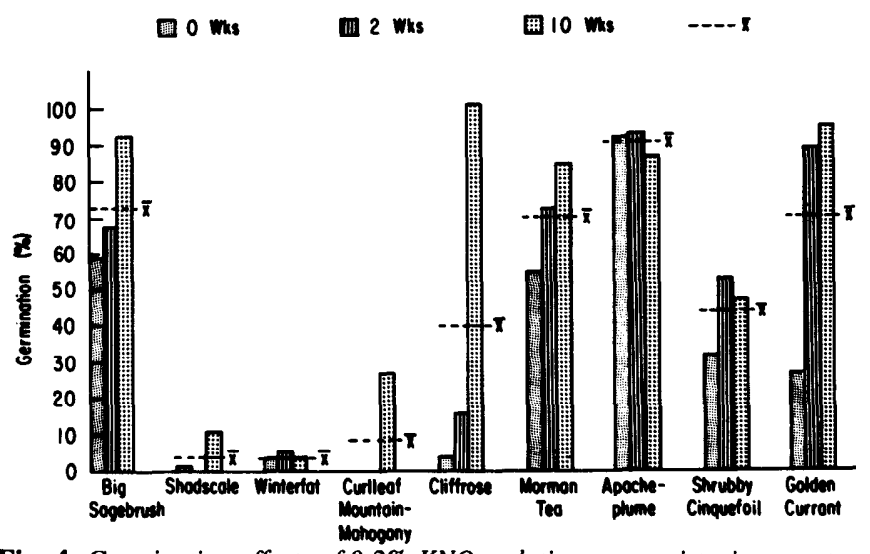

Fig. 4. Germination effects of $0.2 \% \mathrm{KNO}_{3}$ solution as a moistening agent o seeds of nine browse species prechilled for 0,2 , and 10 weeks. Time > Treatment $L S D_{0.05}$ : big sagebrush, 30.0; shadscale, 12.0' winterfat, 7.6 curlleaf mountain-mahogany, 9.5 ; cliffrose, 7.3; Morman tea, 14.6 Apache-plume, 17.4; shrubby cinquefoil, 17.3; golden currant, 18.2 
periods too short to effectively promote germination of all species studied except golden currant.

\section{Conclusions}

Because many of the shrub species studied are slow to germinate and grow, an understanding of the germination requirements would be advantageous in establishing them on rangelands. It appears highly unlikely that planting seed of bitterbrush, shadscale, big sagebrush, cliffrose, currleaf mountain-mahogany, and golden currant would result in suitable stands if planted in the spring. The prechill requirements for maximum germination suggest that fall planting is required. Other species such as Apache-plume, shrubby cinquefoil, and Morman tea appear to be equally suited to fall and spring establishment. Species, such as winter fat, fourwing saltbrush, and Jersey tea, requiring no prechill or a short prechill duration could be planted in the spring. However, spring seedlings often have a high mortality since drought conditions occur before plants can establish a supportive root system.

\section{Literature Cited}

Amen, R.D. 1963. The concept of seed dormancy. Amer. Sci. 51:408-424.

Barr, A.J., and J.H. Goodnight. 1972. A user's guide to the statistical analysis system. North Carolina Univ. Raleigh, N.C. 360 p.

Cable, D.R. 1972. Fourwing saltbush revegetation trials in southern Arizona. J. Range Manage. 25:150-153.

Applications are invited for the position of Assistant Professor in the Department of Animal Science, University of British Columbia. Candidates must hold the Ph.D. degree, and be eligible for membership in the British Columbia Institute of Agrologists. Post-graduate training and experience in the area of beef cattle nutrition is essential. Background in the animal aspects of range management, and in systems modelling, would be highly desirable.

The successful candidate will be expected to participate in the teaching of undergraduate and graduate courses, to undertake research in the beef cattle producing areas of interior British Columbia, and to participate in the on-campus beef cattle research program.

Applications, including curriculum vitae, and the names of three referees should be sent to:

\section{Dr. B.D. Owen, Chairman \\ Department of Animal Science \\ Faculty of Agricultural Sciences \\ The University of British Columbia \\ Suite 248, 2357 Main Maill \\ Vancouver, British Columbia V6T 2 A2}

The University of British Columbia offers equal opportunity of employment to qualified male or female candidates.
Carlson, J. 1974. Propagation of high elevation shrubs, p. 91-109. In: Erosion Control Symp., Proc. Sacramento, Calif. U.S. Dep. Agr. Soil Conserv. Serv. and Ext. Serv. Univ. Calif.

Everett, R.L., and R.O. Meeuwing. 1975. Hydrogen peroxide and thiourea treatment of bitterbrush seed. U.S. Dep. Agr. Forest Serv. Intermountain Forest and Range Exp. Sta. Res. Note. 97. 5 p.

Liacos, L.G., and E.C. Nord. 1961. Curlleaf cercocarpus seed dormancy yields to acid and thiourea. J. Range Manage. 14:317-320.

Mayer, A.M., and A. Poljakoff-Mayber. 1975. The germination of seeds. 2nd ed. Pergamon Press, New York. 192 p.

McConnell B.R. 1960. Effect of gibberellic acid and cold treatments on germination of bitterbrush seed. U.S. Dep. Agr. Forest Serv. Pacific Northwest Forest and Range Exp. Sta. Res. Note 197. 4 p.

McHenry, W.B., and L.A. Jensen. 1967. Response of bitterbrush (Purshia tridentata) seed to certain germination methods. Ass. Off. Seed Anal. North Amer. Proc. 57:89-95.

Mirov, N.T. 1936. Germination behavior of some California plants. Ecology 17:667-672.

Pearson, B.O. 1957. Bitterbrush seed dormancy broken with thiourea. J. Range Manage. 10:41-42.

Shopmeyer, C.S., tech. coordinator. 1974. Seeds of woody plants in the United States. For. Serv., U.S. Dep. Agr. Handbook 450. Washington, D.C. $883 \mathrm{p}$.

Stevens, R., B.C. Guinta, K.R. Jorgenson, and A.P. Plummer. 1977. Winterfat Utah State Div. Wildl. Res. Pub. No. 77-2. Logan, Utah. 41 p.

U.S. Dep. Agr. Forest Service. 1977. Intermountain range plant names and symbols. U.S. Dep. Agr. Forest Serv. Gen. Tech. Rep. INT-38. 82 p.

U.S. Dep. Agr. Soil Conserv. Serv. 1971. National list of scientific plant names. Lincoln. $281 \mathrm{p}$.

Walters, G.L. 1970. Breaking dormancy of longleaf uniola seeds. J. Range Manage. 23:178-180.

Young, J.A., R.A. Evans, and D.L. Neal. 1978. Treatment of curlleaf cercocarpus seeds to enhance germination. J. Wildl. Manage. 42:614-620.

Research Associate, Range Improvement/Brush and Weed Control at the Texas A\&M University Agricultural Research and Extension Center at San Angelo. Responsibilities include assisting with ongoing research in prescribed burning, brush and weed control and ecology, and revegetation as well as initiating and conducting original research in these areas. Salary $\$ 14,000$ per annum. M.S. degree required. Submit resumé with three references to: Dr. Darrell N. Ueckert, Associate Professor, Texas A\&M University Agricultural Research and Extension Center, Route 2, Box 950, San Angelo, Texas 76901. 